\title{
1,25 Dihydroxyvitamin D Increases Hepatocyte Cytosolic Calcium Levels A Potential Regulator of Vitamin D-25-Hydroxylase
}

\author{
Daniel T. Baran and Moira L. Milne \\ Departments of Orthopedics and Medicine, University of Massachusetts Medical Center, \\ Worcester, Massachusetts 01605
}

\begin{abstract}
1,25 dihydroxyvitamin $\mathrm{D}\left(1,25(\mathrm{OH})_{2} \mathrm{D}\right)$ has been demonstrated to inhibit hepatic 25 hydroxyvitamin D (25 OHD) production. Changes in cytosolic calcium have been shown to regulate cellular processes. Using the fluorescent dye Quin 2, we have investigated the effects of $1,25(\mathrm{OH})_{2} \mathrm{D}$ and $24,25(\mathrm{OH})_{2} \mathrm{D}$ on cytosolic calcium levels in hepatocytes. $1,25(\mathrm{OH})_{2} \mathrm{D}$ exposure for $5 \mathrm{~min}$ increases cytosolic calcium levels by $24 \%$ at a concentration of $100 \mathrm{pg} /$ $\mathrm{ml}, 39 \%$ at a concentration of $1 \mathrm{ng} / \mathrm{ml}$, and $50 \%$ at a concentration of $2 \mathrm{ng} / \mathrm{ml}$. The latter increment occurs in both the presence and absence of extracellular calcium, indicating that $1,25(\mathrm{OH})_{2} \mathrm{D}$ is mobilizing intracellular calcium pools. $24,25(\mathrm{OH})_{2} \mathrm{D}, 10 \mathrm{ng} / \mathrm{ml}$, does not increase cytosolic calcium levels while the calcium ionophore A23187, $3 \mu \mathrm{M}$, increases levels by 52\%. Calcium inhibits hepatic 25 OHD synthesis in liver homogenates in a dose-dependent fashion, which can be prevented by chelation of calcium with EGTA. 1,25(OH) 2 D and A23187 decrease hepatocyte 25 OHD synthesis. The inhibitory effect of $A 23187 \mathrm{can}$ be prevented by chelation of extracellular calcium. The data demonstrate that $1,25(\mathrm{OH})_{2} \mathrm{D}$ increases hepatocyte cytosolic calcium, and that these increments in cytosolic calcium may regulate some of the hepatic actions of the vitamin D metabolite.
\end{abstract}

\section{Introduction}

Current evidence suggests that the calcium ion is an intracellular messenger in hormone action and that alterations in cytosolic calcium concentrations are instrumental in hormone synthesis and secretion. Calcium is known to play an important role in insulin release $(1,2)$ and recent reports indicate that 1,25 dihydroxyvitamin $\mathrm{D}\left(1,25(\mathrm{OH})_{2} \mathrm{D}\right)^{1}$ is essential for normal insulin secretion in the perfused rat pancreas (3), suggesting a possible relationship between $1,25(\mathrm{OH})_{2} \mathrm{D}$ and intracellular calcium levels.

Recent studies have begun to examine the regulation of 25 hydroxyvitamin D (25 OHD) and the effect of disease on this process. $1,25(\mathrm{OH})_{2} \mathrm{D}$ inhibits $25 \mathrm{OHD}$ production by the per-

\footnotetext{
Address correspondence to Dr. Baran.

Received for publication 3 June 1985 and in revised form 3 February
} 1986.

1. Abbreviations used in this paper: $25 \mathrm{OHD}, 25$ hydroxyvitamin $\mathrm{D}$; $1,25(\mathrm{OH})_{2} \mathrm{D}, 1,25$ dihydroxyvitamin $\mathrm{D} ; 24,25(\mathrm{OH})_{2} \mathrm{D}, 24,25$ dihydroxyvitamin D; BGJ, Biggers-Gwatkin-Judah; buffered salt solution; DMSO, dimethylsulfoxide; $F_{\max }$, maximal fluorescence; $F_{\min }$, minimal fluorescence; HPLC, high performance liquid chromatography.

\footnotetext{
J. Clin. Invest.

(c) The American Society for Clinical Investigation, Inc.

0021-9738/86/05/1622/05 \$1.00

Volume 77, May 1986, 1622-1626
}

fused rat liver and rat liver homogenates within $2 \mathrm{~h}$ (4). Inhibition of $25 \mathrm{OHD}$ synthesis by $1,25(\mathrm{OH})_{2} \mathrm{D}$ is greater in the perfused liver $(45 \%)$ than in liver homogenates $(11 \%)$, suggesting that the $1,25(\mathrm{OH})_{2} \mathrm{D}$ effect is augmented in the intact system (4). Circulating $1,25(\mathrm{OH})_{2} \mathrm{D}$ levels also inhibit hepatic $25 \mathrm{OHD}$ production in humans. Administration of $1,25(\mathrm{OH})_{2} \mathrm{D}$ to postmenopausal women with osteoporosis is attended by a significant decrease in circulating levels of $25 \mathrm{OHD}$ (5). Likewise, treatment of normal subjects with $1,25(\mathrm{OH})_{2} \mathrm{D}$ prevents an increase in serum $25 \mathrm{OHD}$ levels in response to a challenge with vitamin $\mathrm{D}(6)$.

We have investigated the effects of $1,25(\mathrm{OH})_{2} \mathrm{D}$ on hepatocyte cytosolic calcium levels, and of calcium on hepatic 25 OHD production. The results indicate that (1) the vitamin D metabolite increases hepatocyte cytosolic calcium levels in a dose-dependent fashion; (2) the calcium ion inhibits 25 OHD synthesis by rat liver homogenates also in a dose-dependent fashion; and (3) the calcium ionophore which also increases cytosolic calcium inhibits hepatocyte 25 OHD production. The data suggest that the $1,25(\mathrm{OH})_{2} \mathrm{D}$-induced increments in cytosolic calcium may mediate some of the actions of this vitamin $\mathrm{D}$ metabolite.

\section{Methods}

Animal maintenance. All rats are housed in the vivarium at the University of Massachusetts Medical Center. When vitamin D-deficient animals are required, 3-wk-old male weanling rats are housed in the absence of ultraviolet light and fed a vitamin D-deficient diet (Teklad, Madison, WI) containing $0.2 \%$ calcium and $0.4 \%$ phosphate for $8 \mathrm{wk}$. At that time blood levels of $25 \mathrm{OHD}$ are $0.8 \pm 0.3 \mathrm{ng} / \mathrm{ml}, 1,25(\mathrm{OH})_{2} \mathrm{D}$ levels $20 \pm 3 \mathrm{pg} /$ $\mathrm{ml}$, calcium $5.9 \pm 0.2 \mathrm{mg} / \mathrm{dl}$, and phosphorus $10.5 \pm 0.6 \mathrm{mg} / \mathrm{dl}$.

Hepatocyte preparation. The liver is perfused for $30 \mathrm{~min}$ in the presence of collagenase (Cooper Biomedical, Inc., Malvern, PA), $0.15 \mathrm{mg} /$ $\mathrm{ml}$, in a perfusate buffer system containing $2.5 \%$ washed red blood cells and $97.5 \%$ Hepes-buffered salt solution (BSS) without calcium or magnesium. The temperature in the perfusion chamber is $37^{\circ} \mathrm{C}$ with a humidity of $90-93 \%$. The $\mathrm{pO}_{2}$ of the perfusion solution is maintained at $100 \mathrm{~mm} \mathrm{Hg}$ by a constant flow of $95 \% \mathrm{O}_{2} / 5 \% \mathrm{CO}_{2}$ (5 liters/min) through the "lung" assembly within the perfusion chamber. Details of the surgical procedure are given elsewhere (7).

After taking the liver from the perfusion chamber, the connective tissue is removed and the liver sliced into small pieces in serum-free Hepes-BSS containing $1.5 \mathrm{~g} / \mathrm{dl}$ albumin. The BSS contains $\mathrm{NaCl} 124$ $\mathrm{mM}, \mathrm{NaHCO}_{3} 18.3 \mathrm{mM}, \mathrm{KCl} 5 \mathrm{mM}, \mathrm{KH}_{2} \mathrm{PO}_{4} 1 \mathrm{mM}, \mathrm{MgSO}_{4} / 7 \mathrm{H}_{2} \mathrm{O} 1$ $\mathrm{mM}, \mathrm{CaCl}_{2} / \mathrm{H}_{2} \mathrm{O} 1.8 \mathrm{mM}$, and glucose $11 \mathrm{mM}$ with a $\mathrm{pH}$ of 7.4 at $37^{\circ} \mathrm{C}$. The calcium ion concentration is $0.5 \mathrm{mM}$. The homogenate is filtered through fine mesh and centrifuged at $50 \mathrm{~g}$ for $1 \mathrm{~min}$. The pellet is resuspended in the Hepes-BSS at $37^{\circ} \mathrm{C}$, washed, and recentrifuged a total of three times. The cell viability is determined by trypan blue dye exclusion. The viability for vitamin D-deficient hepatocytes is $60-72 \%$, comparable to the $58 \%$ viability reported by others (8), yielding $20-40$ $\times 10^{7}$ viable hepatocytes/liver.

Determination of cytosolic calcium levels by Quin 2 fluorescence. Hepatocytes, $5 \times 10^{7}$ cells, are incubated in a water bath for $10 \mathrm{~min}$ in $5 \mathrm{ml}$ of Hepes-BSS containing $1.5 \mathrm{~g} / \mathrm{dl}$ albumin at $37^{\circ} \mathrm{C}$ under $95 \% \mathrm{O}_{2} /$ 
$5 \% \mathrm{CO}_{2}$ at 60 oscillations/min. Quin 2AM (CalBiochem-Behring Corp., San Diego, CA), $500 \mathrm{nmoles,} \mathrm{in} 5 \mu \mathrm{l}$ of DMSO, is added to $5 \mathrm{ml}$ of cells for $15 \mathrm{~min}$. The cells are diluted to $15 \mathrm{ml}$ with the Hepes-BSS (without albumin) and centrifuged at $50 \mathrm{~g}$. They are resuspended in $5 \mathrm{ml}$ of HepesBSS (without albumin) and incubated for an additional $15 \mathrm{~min}$.

Cellular fluorescence is determined in a 650-10S Scanning Fluorescence Spectrophotometer (Perkin-Elmer Corp., Norwalk, CT). Fluorescence readings $(F)$ are taken at an emission wavelength of $495 \mathrm{~nm}$ and a slit width of $5 \mathrm{~nm}$, and an excitation wavelength of $339 \mathrm{~nm}$ and a slit width of $5 \mathrm{~nm}$ with constant stirring (Spectrocell, Inc., Oreland, PA). The emission spectrum is determined by scanning between an emission of $380 \mathrm{~nm}$ and $530 \mathrm{~nm}$. Recordings are made on an R100A recorder (Perkin-Elmer Corp.). Maximal fluorescence is determined by the addition of $100 \mu \mathrm{l}$ of $10 \%$ Triton X-100 to lyse $1 \mathrm{ml}$ of cells $\left(F_{\max }\right)$ and minimal fluorescence by the addition of $50 \mu$ l of 1 M EGTA to chelate the calcium $\left(F_{\min }\right)(9)$. The $\mathrm{pH}$ of the lysed cells after addition of EGTA is 8.32. Corrections are made for the fluorescence in dimethylsulfoxide (DMSO)-treated hepatocytes, the quenching of fluorescence due to Triton $\mathrm{X}-100$, and any solvent effects, e.g. alcohol. The cytosolic calcium content is determined by the equation $\left[\mathrm{Ca}^{++}\right]_{\mathrm{i}}=K_{\mathrm{D}}\left(F-F_{\min }\right) /\left(F_{\max }-F\right)$, where the dissociation constant $\left(K_{\mathrm{D}}\right)$ is $115 \mathrm{nM}(9)$. Derivation of the equation has been previously outlined $(10)$. Where indicated, $1,25(\mathrm{OH})_{2} \mathrm{D}$ or 24,25 dihydroxyvitamin $\mathrm{D}\left(24,25(\mathrm{OH})_{2} \mathrm{D}\right)$ (courtesy Hoffman LaRoche Inc., Nutley, NJ) or the calcium ionophore A23187 (Sigma Chemical Co., St. Louis, MO) are added to $1 \mathrm{ml}$ of cells in $10 \mu \mathrm{l} 95 \%$ alcohol for $5 \mathrm{~min}$. Controls are treated with $10 \mu \mathrm{l} 95 \%$ alcohol for $5 \mathrm{~min}$. Probability of difference is determined by Student's paired $t$ test.

Liver homogenate production of $25 \mathrm{OHD}$. The rat liver homogenate is prepared as we have previously described (4). Vitamin D-deficient rats are killed by exsanguination under light ether anesthesia and the livers removed and chilled immediately in ice-cold $0.25 \mathrm{M}$ sucrose. Incubations include $5 \mathrm{ml}$ of the liver homogenate, $2.5 \mathrm{ml}$ of a buffercofactor solution, and $2.5 \mathrm{ml}$ of a salt mixture. The latter consists of 5 $\mathrm{mM} \mathrm{MgCl}$ and $0.1 \mathrm{M} \mathrm{KCl}$ to give final concentrations of $1.25 \mathrm{mM}$ $\mathrm{MgCl}_{2}$ and $25 \mathrm{mM} \mathrm{KCl}$ in the incubation volume. The effect of the divalent ion calcium is studied by removal of equimolar amounts of $\mathrm{MgCl}_{2}$ and substitution with $\mathrm{CaCl}_{2} .2$ pmol of $\left[{ }^{3} \mathrm{H}\right]$ vitamin $\mathrm{D}, 22 \mathrm{Ci} /$ mmol (Amersham Corp., Arlington Heights, IL) are added to each flask in $25 \mu 195 \%$ alcohol. Incubations are carried out for $3 \mathrm{~h}$ and terminated as previously described (4). The identity of the $\left[{ }^{3} \mathrm{H}\right] 25 \mathrm{OHD}$ is confirmed by cochromatography with authentic 25 OHD (courtesy D. J. Babcock, Upjohn Co., Kalamazoo, MI) on Sepadex LH 20 and high-performance liquid chromatography (HPLC). The protein concentration is determined by the method of Lowry (11) and the data expressed as pmol $\left[{ }^{3} \mathrm{H}\right] 25$ $\mathrm{OHD} / \mathrm{g}$ protein per $3 \mathrm{~h}$. In those studies where EGTA is included in the homogenate mixture, the compound is added at the start of the 3-h incubation. Probability of difference is determined by analysis of variance.

Hepatocyte production of 25 OHD. Hepatocytes $\left(1 \times 10^{7}\right.$ viable cells $)$ are suspended in $5 \mathrm{ml}$ Biggers-Gwatkin-Judah (BGJ) culture medium containing albumin, $1 \mathrm{~g} / \mathrm{dl}$, and $5 \mathrm{ml}$ of a salt-cofactor solution (4). The final incubation volume is $10 \mathrm{ml}$ and contains $2 \mathrm{pmol}\left[{ }^{3} \mathrm{H}\right]$ vitamin $\mathrm{D}$. $1,25(\mathrm{OH})_{2} \mathrm{D}, 2 \mathrm{ng} / \mathrm{ml}, \mathrm{A} 23187,3 \mu \mathrm{M}$, and EGTA, $1.5 \mathrm{mM}$, are added to the appropriate flasks. Incubations are carried out for $90 \mathrm{~min}$ at $37^{\circ} \mathrm{C}$ and 60 oscillations per min, at which time cell viability is determined by trypan dye exclusion and the reactions terminated by addition of 25 $\mathrm{ml} \mathrm{MeOH}$ and $12.5 \mathrm{ml} \mathrm{CHCl}_{3}$. The identity of the $\left[{ }^{3} \mathrm{H}\right] 25 \mathrm{OHD}$ is confirmed as above and data expressed as picomoles $\left[{ }^{3} \mathrm{H}\right] 25$ OHD produced per $10^{7}$ cells per $90 \mathrm{~min}$. Probability of difference is determined by Student's $t$ test.

\section{Results}

As seen in Fig. 1, the fluorescence emission spectrum of DMSOtreated hepatocytes at an excitation of $339 \mathrm{~nm}$ shows a maximum fluorescence between 450 and $470 \mathrm{~nm}$ and residual fluorescence at $495 \mathrm{~nm}$. This autofluorescence is partly attributed to nucleotides within the cell. Quin 2-loaded hepatocytes demonstrate a

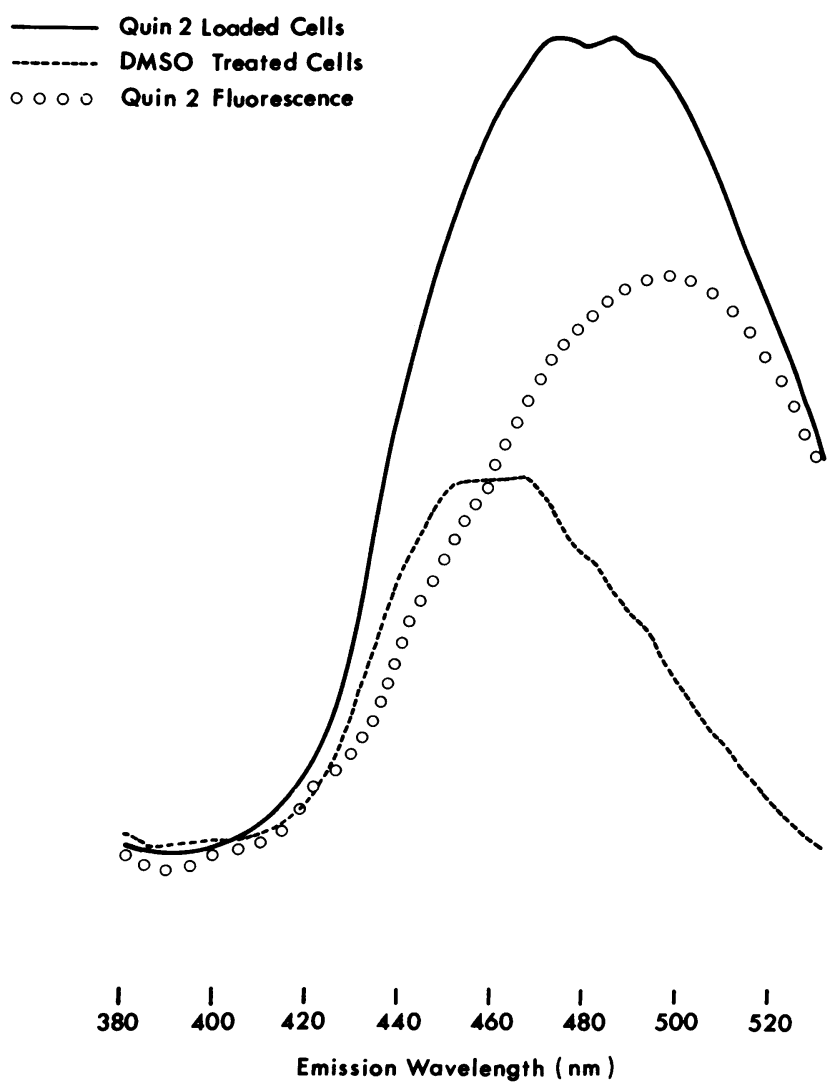

Figure 1. Emission spectrum of hepatocytes. Emission spectrum of 1 $\mathrm{ml}$ of Quin 2-loaded and $1 \mathrm{ml}$ of DMSO-treated hepatocytes containing $10 \mu \mathrm{l}$ alcohol is measured between 380 and $530 \mathrm{~nm}$. The emission spectrum for Quin 2 fluorescence is determined by subtracting the autofluorescence of the DMSO-treated cells from the fluorescence of Quin 2-loaded hepatocytes. The fluorescence of Quin 2 peaks between emission wavelengths of 490 and $500 \mathrm{~nm}$.

maximal fluorescence between 470 and $490 \mathrm{~nm}$. Subtraction of the autofluorescence of hepatocytes from the fluorescence of Quin 2-loaded cells reveals the emission spectrum for Quin 2, peaking between 490 and $500 \mathrm{~nm}$ (circles, Fig. 1). Treatment of Quin 2-loaded hepatocytes incubated in medium containing $0.5 \mathrm{mM}$ calcium with $1,25(\mathrm{OH})_{2} \mathrm{D}, 100 \mathrm{pg} / \mathrm{ml}$, for $5 \mathrm{~min}$ increases the fluorescence of the cells (Fig. 2). This increment occurs gradually during the 5-min period while the fluorescence of alcohol-treated cells remains stable (Fig. 3). At the end of this 5 -min period, fluorescence in the supernatant of control and $1,25(\mathrm{OH})_{2} \mathrm{D}$ treated cells is identical, indicating that the increase in fluorescence is from within the cells and not due to leakage of Quin 2 into the medium. 1,25(OH) $2 \mathrm{D}, 100 \mathrm{pg} / \mathrm{ml}$, increases hepatocyte cytosolic calcium levels by $24 \%$ ( $197 \pm 18$ vs. $244 \pm 21$ $\mathrm{nM}, P<0.001, n=17)$, while $1,25(\mathrm{OH})_{2} \mathrm{D}, 1 \mathrm{ng} / \mathrm{ml}$, increases levels by $39 \%(203 \pm 12$ vs. $282 \pm 41 \mathrm{nM}, P<0.04, n=4)$. At a concentration of $2 \mathrm{ng} / \mathrm{ml}, 1,25(\mathrm{OH})_{2} \mathrm{D}$ treatment results in a $50 \%$ increase in cytosolic calcium levels $(224 \pm 26$ vs. $337 \pm 57$ $\mathrm{nM}, P<0.04, n=9)$. In order to determine whether $1,25(\mathrm{OH})_{2} \mathrm{D}$ is increasing cytosolic calcium by increasing membrane transport of calcium or by mobilizing intracellular calcium stores, $24 \mu \mathrm{l}$ of $1 \mathrm{M}$ EGTA are added per milliliter of cells to chelate extracellular calcium prior to the addition of the vitamin $D$ metabolite. In the absence of extracellular calcium, $1,25(\mathrm{OH})_{2} \mathrm{D}, 2 \mathrm{ng} / \mathrm{ml}$, 


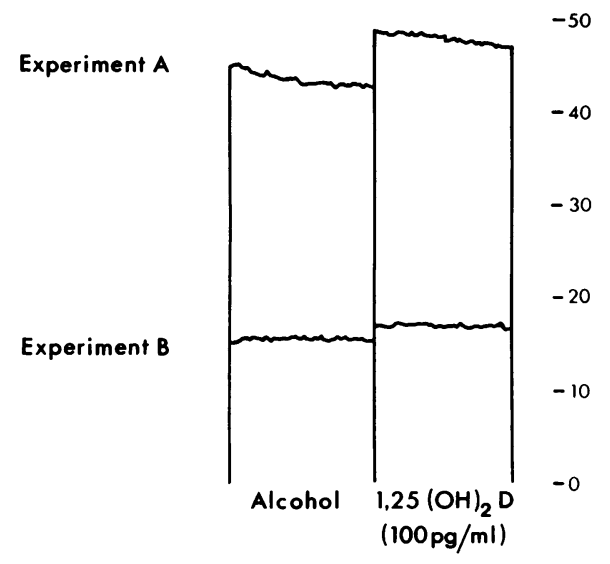

Figure 2. 1,25(OH) $)_{2} \mathrm{D}$ increases cellular fluorescence. The effect of $1,25(\mathrm{OH})_{2} \mathrm{D}, 100 \mathrm{pg} / \mathrm{ml}$, on cellular fluorescence is measured in two cell preparations (experiments $A$ and $B$ ) after 5 min of exposure to either $10 \mu \mathrm{l}$ alcohol or $1,25(\mathrm{OH})_{2} \mathrm{D}$ in $10 \mu \mathrm{l}$ of alcohol. For demonstration purposes the fluorescence of each control preparation is arbitrarily set on the recorder. Readings are obtained at an excitation of 339 $\mathrm{nm}$, emission of $495 \mathrm{~nm}$ with slit widths of $5 \mathrm{~nm}$. Chart speed is 60 $\mathrm{mm} / \mathrm{min}$ with a sensitivity range of $1,000 \mathrm{mV} .1,25(\mathrm{OH})_{2} \mathrm{D}$ increases fluorescence by $4 \mathrm{U}$ in experiment $A$ and $2 \mathrm{U}$ in $B$.

increases hepatocyte cytosolic calcium levels by $56 \%(204 \pm 21$ vs. $318 \pm 65 \mathrm{nM}, P<0.01, n=5)$. In contrast, $24,25(\mathrm{OH})_{2} \mathrm{D}, 10$ $\mathrm{ng} / \mathrm{ml}$, has no effect on cytosolic calcium levels (183 \pm 35 vs. $188 \pm 37 \mathrm{nM}, n=6) .1,25(\mathrm{OH})_{2} \mathrm{D}$ and $24,25(\mathrm{OH})_{2} \mathrm{D}$ have no effect on the autofluorescence of the DMSO-treated hepatocytes. At a concentration of $2 \mathrm{ng} / \mathrm{ml}, 1,25(\mathrm{OH})_{2} \mathrm{D}$ decreases hepatocyte 25 OHD production by $32 \%(0.28 \pm 0.02$ vs. $0.19 \pm 0.01 \mathrm{pmol}$ $\left[{ }^{3} \mathrm{H}\right] 25 \mathrm{OHD}$ produced $/ 10^{7}$ cells per $\left.90 \mathrm{~min}, P<0.01, n=4\right)$.

As seen in Fig. 4, addition of $\mathrm{CaCl}_{2}$ to the liver homogenate inhibits $\left[{ }^{3} \mathrm{H}\right] 25 \mathrm{OHD}$ production. The control incubation containing $1.25 \mathrm{mM} \mathrm{MgCl}_{2}$ and $25 \mathrm{mM} \mathrm{KCl}$ is represented by the bar at the far left. Decreasing the $\mathbf{M g C l}_{2}$ concentration to 0.85 $\mathrm{mM}$ and increasing the $\mathrm{KCl}$ to $33 \mathrm{mM}$ has no effect on $\left[{ }^{3} \mathrm{H}\right] 25$ $\mathrm{OHD}$ production. Although $\mathrm{CaCl}_{2}$ at concentrations of 0.05 and $0.1 \mathrm{mM}$ has no effect on $\left[{ }^{3} \mathrm{H}\right] 25$ OHD by the homogenates, synthesis in the presence of $0.2 \mathrm{mM} \mathrm{CaCl}_{2}$, representing an ultrafilterable calcium concentration of $70 \mu \mathrm{M}(12)$, is decreased by $37 \%, P<0.02$, and is further decreased by greater concentrations of $\mathrm{CaCl}_{2}$ (Fig. 4). EGTA alone has no effect on $\left[{ }^{3} \mathrm{H}\right] 25$ OHD synthesis. However, incubation of the liver homogenates

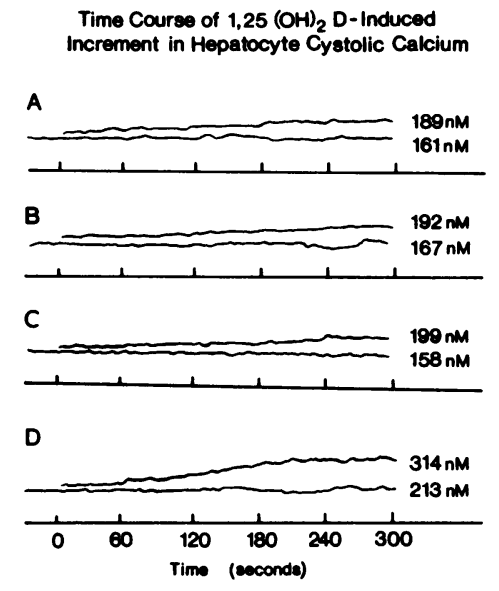

Figure 3. Time course of $1,25(\mathrm{OH})_{2} \mathrm{D}$-induced changes in cytosolic calcium. The effect of $1,25(\mathrm{OH})_{2} \mathrm{D}$ on cellular fluorescence is measured over 5 min with constant stirring. Control cells were treated with ethanol, $10 \mu \mathrm{l}$. The sensitivity range is $1,000 \mathrm{mV}$. Panels $A, B$, and $C$ demonstrate the effect of $1,25(\mathrm{OH})_{2} \mathrm{D}, 100 \mathrm{pg} / \mathrm{ml}$, on cytosolic calcium levels, while in panel $D$ the concentration of the vitamin $\mathrm{D}$ metabolite is $2 \mathrm{ng} / \mathrm{ml}$.

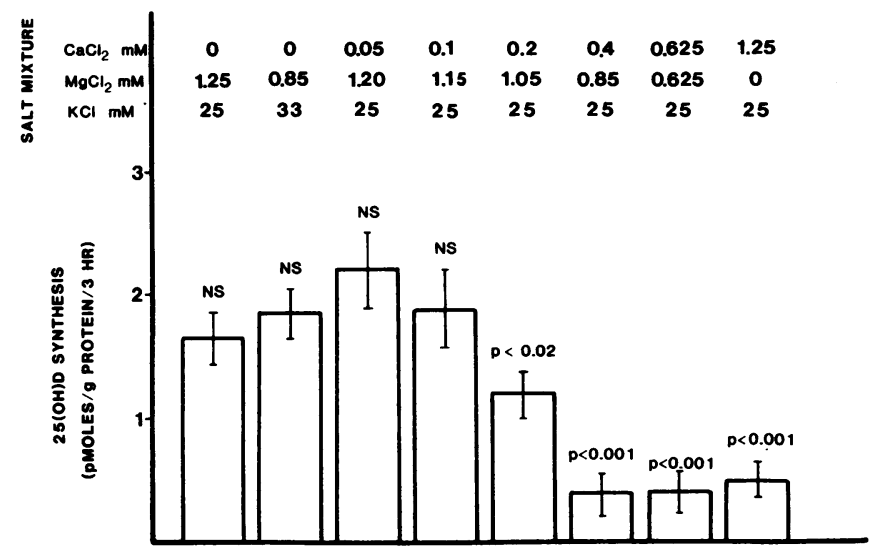

Figure 4. Calcium inhibits 25 OHD synthesis. $\left[{ }^{3} \mathrm{H}\right] 25$ OHD production is determined after $3 \mathrm{~h}$ of incubation of 2 pmol $\left[{ }^{3} \mathrm{H}\right]$ vitamin $\mathrm{D}$ in a 25\% liver homogenate. The effect of $\mathrm{CaCl}_{2}$ is determined by substitution of equimolar amounts of $\mathrm{CaCl}_{2}$ for $\mathrm{MgCl}_{2}$. Values represent the mean \pm SEM of 6-9 separate incubations for each salt mixture.

with $0.4 \mathrm{mM} \mathrm{CaCl}_{2}$ and $5 \mathrm{mM}$ EGTA to chelate the calcium prevents the calcium-induced inhibition $(0.5 \pm 0.1$ vs. $1.3 \pm 0.2$ pmol $\left[{ }^{3} \mathrm{H}\right] 25 \mathrm{OHD} / \mathrm{g}$ liver protein per $3 \mathrm{~h}, P<0.02, n=6$ ), further documenting the role of the calcium ion as the inhibitory agent.

Since the minimum concentration of free calcium required to inhibit $25 \mathrm{OHD}$ synthesis in liver homogenates is $70 \mu \mathrm{M}$ (350 times greater than cytosolic calcium), we examined the effect of increased cytosolic calcium on hepatocyte $25 \mathrm{OHD}$ production. The calcium ionophore $\mathrm{A} 23187,3 \mu \mathrm{M}$, increases hepatocyte cytosolic calcium by $52 \%(196 \pm 11$ vs. $298 \pm 37 \mathrm{nM}, P<0.05$, $n=8)$. Likewise, treatment with the ionophore decreases hepatocyte 25 OHD production $(0.28 \pm 0.02$ vs. $0.20 \pm 0.02$ pmol $\left[{ }^{3} \mathrm{H}\right] 25$ OHD produced $/ 10^{7}$ cells per $\left.90 \mathrm{~min}, P<0.05, n=4\right)$, an effect which is prevented by chelation of extracellular calcium with EGTA $\left(0.28 \pm 0.02\right.$ vs. $0.25 \pm 0.02$ pmol $\left[{ }^{3} \mathrm{H}\right] 25$ OHD produced $/ 10^{7}$ cells per $90 \mathrm{~min}$ ).

\section{Discussion}

The results of this study clearly demonstrate that $1,25(\mathrm{OH})_{2} \mathrm{D}$ is capable of increasing hepatocyte cytosolic calcium levels within $5 \mathrm{~min}$ by mobilizing intracellular calcium stores, that $1,25(\mathrm{OH})_{2} \mathrm{D}$ inhibits hepatocyte $25 \mathrm{OHD}$ production, that the calcium ion inhibits hepatic 25 OHD production in liver homogenates, and that increments in cytosolic calcium induced by the calcium ionophore are associated with decreased hepatocyte $25 \mathrm{OHD}$ production. Alterations in cytosolic calcium levels have been shown to mediate a number of biochemical processes including parathyroid hormone release (13), insulin release $(1,2)$, prolactin release $(10,14)$, and vasopressin-induced increments in hepatocyte phosphorylase activity $(15,16)$. Cytosolic calcium levels in osteoblast-like cells are affected by alterations in extracellular calcium (17), while levels in UMR 106 (18) and SaOS-2 (19) osteogenic sarcoma cells are increased by parathyroid hormone. Since the concentration of calcium required to inhibit 25 OHD production in liver homogenates is supraphysiologic, we have employed the calcium ionophore to increase cytosolic calcium levels to a degree comparable to $1,25(\mathrm{OH})_{2} \mathrm{D}$ treated cells. Ionophore-induced increments of cytosolic calcium within the physiologic range are associated with decreased 25 
OHD production. The ionophore is used to demonstrate the relationship between changes in cytosolic calcium and 25 OHD synthesis rather than $1,25(\mathrm{OH})_{2} \mathrm{D}$, because in addition to increasing cytosolic calcium, the vitamin $\mathrm{D}$ metabolite has also been shown to be a direct noncompetitive inhibitor of the vitamin D 25 hydroxylase in liver homogenates (20). The observation that the ionophore effect is prevented by chelation of extracellular calcium demonstrates that the inhibitory action of A23187 is not a nonspecific toxic effect.

As an intracellular messenger, the free calcium ion concentration of the cytosol is critically important. The free calcium concentration is buffered by binding to proteins in the cytosol, exchange with calcium pools in the microsomes and mitochondria, and transport processes across the plasma membrane (21). Calcium enters the cell by a sodium channel and by a specific calcium channel which is affected by the calcium channel blockers. Cytosolic calcium levels are also regulated by active transport of calcium out of the cell via a specific ATP-dependent calcium pump and $\mathrm{Na}^{+} / \mathrm{Ca}^{++}$exchange (21). Hormone-induced increments in cytosolic free calcium appear to be due to either increased entry into the cell, decreased transport out of the cell, or mobilization of calcium from intracellular pools. In situations where cytosolic calcium increases in the absence of extracellular calcium, changes in phosphatidylinositol metabolism are believed to mediate the process (22). Vasopressin-induced breakdown of polyphosphoinositides in hepatocyte membranes is sufficiently rapid for it to have a primary role in generating messenger signals responsible for intracellular calcium mobilization $(15,16)$. In various cells, both inositol polyphosphates $(16)$ and diacylglycerol (23) have been implicated in the generation of the calcium response.

The rapidity of the $1,25(\mathrm{OH})_{2} \mathrm{D}$-induced effect on hepatocyte cytosolic calcium levels is not unique for this metabolite. $1,25(\mathrm{OH})_{2} \mathrm{D}$ enhances calcium transport in perfused duodena from normal chicks within $14 \mathrm{~min}$ (24). Epithelial cells from normal rat intestine demonstrate increased calcium uptake within 5 min of treatment with $1,25(\mathrm{OH})_{2} \mathrm{D}$ in vitro (25), and calcium uptake of rat intestinal Golgi vesicles is enhanced within $15 \mathrm{~min}$ of $1,25(\mathrm{OH})_{2} \mathrm{D}$ treatment in vivo (26). Therefore, the observations that $1,25(\mathrm{OH})_{2} \mathrm{D}$ increases cytosolic calcium within $5 \mathrm{~min}$ raises the possibility that the mechanism is independent of genome activation, perhaps attributable to a direct interaction with membranes (24).

Other factors in addition to calcium and $1,25(\mathrm{OH})_{2} \mathrm{D}$ have been reported to affect $25 \mathrm{OHD}$ synthesis. Acute phenobarbital treatment (27) and an acid load (28) enhance 25 OHD production, whereas chronic phenobarbital treatment (7), cimetidine and isoniazid (29), and alcohol administration (30) inhibit production.

The vitamin D system is now recognized to play a role in the regulation of hematolymphopoietic tissue (31) as well as the maintenance of mineral and bone homeostasis. The current studies indicate that $1,25(\mathrm{OH})_{2} \mathrm{D}$ increases hepatocyte cytosolic calcium levels by mobilizing intracellular pools, and that these increments may be involved in $1,25(\mathrm{OH})_{2} \mathrm{D}$-induced regulation of 25 OHD production (4-6). The vitamin D endocrine system is thus involved in both extracellular and intracellular calcium homeostasis.

\section{Acknowledgments}

This work was supported in part by National Institutes of Health grant AM35104.

\section{References}

1. Siegel, E. G., C. B. Wollheim, D. Janjic, G. Ribes, and G. W. G. Sharp. 1983. Involvement of $\mathrm{Ca}^{++}$in the impaired glucose-induced insulin release from islets cultured at low glucose. Diabetes. 32:993-1000.

2. Wollheim, C. B., and T. Pozzan. 1984. Correlation between cytosolic free $\mathrm{Ca}^{++}$and insulin release in an insulin-secreting cell line. $J$. Biol. Chem. 259:2262-2267.

3. Kadowaki, S., and A. W. Norman. 1985. Demonstration that the vitamin D metabolite $1,25(\mathrm{OH})_{2}$-vitamin D and not $24,25(\mathrm{OH})_{2}$-vitamin $D$ is essential for normal insulin secretion in the perfused rat pancreas. Diabetes. 34:315-320.

4. Baran, D. T., and M. L. Milne. 1983. 1,25 dihydroxyvitamin Dinduced inhibition of ${ }^{3} \mathrm{H}-25$ hydroxyvitamin $\mathrm{D}$ production by the rachitic rat liver in vitro. Calcif. Tissue Int. 35:461-464.

5. Lore, F., G. DiCairano, P. Periti, and A. Caniggia. 1982. Effect of the administration of 1,25 dihydroxyvitamin $D_{3}$ on serum levels of 25 hydroxyvitamin D in postmenopausal osteoporosis. Calcif. Tissue Int. 34:539-541.

6. Bell, N. H., S. Shaw, and R. T. Turner. 1984. Evidence that 1,25 dihydroxyvitamin $D_{3}$ inhibits the hepatic production of 25 -hydroxyvitamin D in man. J. Clin. Invest. 74:1540-1544.

7. Baran, D. T. 1983. Effect of phenobarbital treatment on metabolism of vitamin D by rat liver. Am. J. Physiol. 245:E55-E59.

8. Dueland, S., I. Holmberg, T. Berg, and J. I. Pedersen. 1981. Uptake and 25-hydroxylation of vitamin $\mathrm{D}_{3}$ by isolated rat liver cells. J. Biol. Chem. 256:10430-10434.

9. Tsien, R. Y., T. Pozzan, and T. J. Rink. 1982. Calcium homeostasis in intact lymphocytes: cytoplasmic free calcium monitored with a new intracellularly trapped fluorescent indicator. J. Cell. Biol. 94:325-334.

10. Albert, P. R., and A. H. Tashjian, Jr. 1984. Thyrotropin-releasing hormone-induced spike and plateau in cytosolic free $\mathrm{Ca}^{++}$concentrations in pituitary cells: relation to prolactin release. J. Biol. Chem. 259:58275832.

11. Lowry, O. H., N. J. Rosebrough, A. L. Farr, and R. J. Randall. 1951. Protein measurement with the folin-phenol reagent. J. Biol. Chem. 193:265-275.

12. Wortsman, J., L. I. Killam, and R. B. Traycoff. 1981. A rapid method for determination of ultrafilterable calcium in serum. J. Lab. Clin. Med. 98:691-696.

13. Shoback, D., J. Thatcher, R. Leombruno, and E. Brown. 1983. Effects of extracellular $\mathrm{Ca}^{++}$and $\mathrm{Mg}^{++}$on cytosolic $\mathrm{Ca}^{++}$and PTH release in dispersed bovine parathyroid cells. Endocrinology. 113:424-426.

14. Kut-Nie, T., and A. H. Tashjian, Jr. 1984. Voltage-dependent calcium channels in pituitary cells in culture: participation in thyrotropin releasing hormone action on prolactin release. J. Biol. Chem. 259:427434.

15. Thomas, A. P., J. S. Marks; K. E. Coll, and J. R. Williamson. 1983. Quantitation and early kinetics of inositol lipid changes induced by vasopressin in isolated cultured hepatocytes. J. Biol. Chem. 258:57165725.

16. Thomas, A. P., J. Alexander, and J. R. Williamson. 1984. Relationship between inositol polyphosphate production and the increase of cytosolic free $\mathrm{Ca}^{++}$induced by vasopressin in isolated hepatocytes. $J$. Biol. Chem. 259:5574-5584.

17. Rizzoli, R., H. Fleisch, and V. von Tscharner. 1984. Determination of free cytoplasmic calcium in cultured bone cells. Calcif. Tissue Int. 36:521. (Abstract).

18. Lowik, C. W. G. M., J. P. T. M. von Leeuwen, J. H. M. Fegen, and M. P. M: Hermann-Erlee. 1984. Cytosolic free $\mathrm{Ca}^{++}$in UMR osteogenic sarcoma cells measured by Quin 2: Effects of PTH and different drugs. Calcif. Tissue Int. 36:526. (Abstr.).

19. Boland, C. J., and A. H. Tashjian, Jr. 1984. Measurement of cytosolic free $\mathrm{Ca}^{+2}$ in human and rat osteosarcoma cell lines: Action of bone resorption stimulating hormones. Calcif. Tissue Int. 36:453. (Abstr.).

20. Milne, M. L., and D. T. Baran. 1985. End product inhibition of hepatic 25-hydroxyvitamin D production: specificity and kinetics. Arch. Biochem. Biophys. 242:488-492, 1985. 
21. Rasmussen, H., and D. Waisman. 1981. The messenger function of calcium in endocrine systems. In Biochemical Action of Hormones. G. Litwack, editor. Academic Press, New York. 1-52.

22. Berridge, M. J. 1982. A novel cellular signalling system based on the integration of phospholipid and calcium metabolism. In Calcium and Cell Function. Volume III. W. Y. Cheung, editor. Academic Press, New York. 1-36.

23. Mattin, T. F. J., and J. A. Kowalchyk. 1984. Evidence for the role of calcium and diacylglycerol as dual second messengers in thyrotropin releasing hormone action: involvement of diacylglycerol. Endocrinology. 115:1517-1526.

24. Nemere, I., Y. Yoshimoto, and A. W. Norman. 1984. Calcium transport in perfused duodena from normal chicks: enhancement within fourteen minutes of exposure to 1,25 dihydroxyvitamin D. Endocrinology. 115:1476-1483.

25. Nemere, I., and C. M. Szego. 1981. Early actions of parathyroid hormone and 1,25 dihydroxycholecalciferol on isolated epithelial cells from rat intestine: limited lysozymal enzyme release and calcium uptake. Endocrinology. 108:1450-1462.
26. MacLaughlin, J. A., M. M. Weiser, and R. A. Freedman. 1980. Biphasic recovery of vitamin $\mathrm{D}$ dependent $\mathrm{Ca}^{++}$uptake by rat intestinal Golgi membranes. Gastroenterology. 72:325-332.

27. Baran, D. T., A. C. Fausto, M. L. Robert, I. Karl, and L. V. Avioli. 1979. Phenobarbital induced alterations in the metabolism of $\left[{ }^{3} \mathrm{H}\right.$ ] vitamin D by the perfused rat liver. J. Clin. Invest. 64:1112-1117.

28. Milne, M. L., and D. T. Baran. 1985. Acute metabolic acidosis stimulates ${ }^{3} \mathrm{H}-25$ hydroxyvitamin $D$ production by the rachitic rat liver. Calcif. Tissue Int. 37:77-81.

29. Bengoa, J. M., M. J. G. Bolt, and I. H. Rosenberg. 1984. Hepatic vitamin D-25-hydroxylase inhibition by cimetidine and isoniazid. J. Lab. Clin. Med. 104:546-552.

30. Milne, M. L., and D. T. Baran. 1985. Inhibitory effect of maternal alcohol ingestion on rat pup hepatic 25 hydroxyvitamin $D$ production. Pediatr. Res. 19:102-104.

31. Manolagas, S. C., and L. F. Deftos. 1984. The vitamin D endocrine system and the hematolymphopoietic tissue. Ann. Intern. Med. 100:144146. 